Check for updates

Cite this: J. Mater. Chem. B, 2021 9, 8081

Received 9th April 2021,

Accepted 24th August 2021

DOI: $10.1039 / \mathrm{d} 1 \mathrm{tb} 00789 \mathrm{k}$

rsc.li/materials-b

\section{Influence of surface topography on PCL electrospun scaffolds for liver tissue engineering}

\author{
Yunxi Gao (D) and Anthony Callanan (D) *
}

Severe liver disease is one of the most common causes of death globally. Currently, whole organ transplantation is the only therapeutic method for end-stage liver disease treatment, however, the need for donor organs far outweighs demand. Recently liver tissue engineering is starting to show promise for alleviating part of this problem. Electrospinning is a well-known method to fabricate a nanofibre scaffold which mimics the natural extracellular matrix that can support cell growth. This study aims to investigate liver cell responses to topographical features on electrospun fibres. Scaffolds with large surface depression $(2 \mu \mathrm{m})$ (LSD), small surface depression $(0.37 \mu \mathrm{m})$ (SSD), and no surface depression (NSD) were fabricated by using a solvent-nonsolvent system. A liver cell line (HepG2) was seeded onto the scaffolds for up to 14 days. The SSD group exhibited higher levels of cell viability and DNA content compared to the other groups. Additionally, the scaffolds promoted gene expression of albumin, with all cases having similar levels, while the cell growth rate was altered. Furthermore, the scaffold with depressions showed 0.8 MPa higher ultimate tensile strength compared to the other groups. These results suggest that small depressions might be preferred by HepG2 cells over smooth and large depression fibres and highlight the potential for tailoring liver cell responses.

\section{Introduction}

Approximately 2 million people per year die worldwide due to liver disease. ${ }^{1}$ Over 600000 people in the UK have cirrhosis and since the 1970s the number of deaths due to liver disease has increased by $400 \% .^{2}$ A report published by the Lancet Commission on liver disease in the UK in 2018 indicated that in the future it could overtake heart disease as the biggest cause of death. ${ }^{3}$ Unfortunately, the only effective way to treat liver disease still remains whole liver transplantation, while donor liver demands far outweigh this supply. ${ }^{2}$

Liver tissue engineering is modern biotechnology that is based on combining hepatocyte transplantation with a biomaterial which can mimic a liver tissue environment. ${ }^{4}$ This approach can allow cells to survive long-term and maintain a functional phenotype in vitro, which eventually may permit the restoration or replacement of liver functions in the clinical sector. ${ }^{5-8}$ Current research in the field is examining the potential of decellularized whole organ extracellular matrix as one potential avenue to deal with organ shortage. The whole human liver can be decellularized and repopulated with stem cells, which has been shown to exhibit good viability with some function. ${ }^{9,10}$ However, decellularization requires large human or animal resources, which are known to have a wide batch to batch variation. ${ }^{11}$

Institute of Bioengineering, School of Engineering, The University of Edinburgh, Edinburgh, UK. E-mail: Anthony.Callanan@ed.ac.uk; Tel: +44(0)131 6507355
Tissue engineering offers a potential solution to tackle these variations in natural occurring tissue. New functional tissues can be generated from polymer scaffolds with 3D porous structures, designed to support cell attachment, migration, function and cell-material interactions. ${ }^{12} 3 \mathrm{D}$ printing, freeze drying, melt drawing and electrospinning are common techniques which can be used to make a cell scaffold. ${ }^{4,13,14}$ However, compared to other methods, electrospinning can fabricate nonwoven fibre mats which can closely mimic the structure of the natural extracellular matrix (ECM), and allow a lot of control in the fabrication process. ${ }^{15-24}$ Polycaprolactone (PCL) is one such polymer that has shown good biocompatibility, biodegradability and mechanical properties, which is commonly used in electrospinning to make cell scaffolds. ${ }^{25}$

In recent studies, electrospinning has provided significant contributions to liver tissue engineering. ${ }^{26-37}$ In particular one study combined electrospinning and laparoscope techniques to deliver nanofibres directly into the liver of a living pig, and the results showed advantages such as less inflammatory responses and faster recovery than other traditional methods. ${ }^{34}$ Also it is an excellent way to combine other proteins such as liver ECM, collagen, fibronectin and chitosan to create a tailored scaffold to influence hepatocyte phenotype. $^{27,32,33}$ In one scaffold composed of nanoporous PLLA electrospun fibres coated with type I collagen promoted liver-specific functions of primary hepatocytes. ${ }^{19}$ Interestingly, one highlight from recent studies also confirmed electrospun PCL mats can exhibit some similar responses to original liver tissue. ${ }^{35}$ 
It has been shown that the morphology of fibres can significantly effect cell behaviour and growth. ${ }^{2,17}$ With fibre alignment publicised to affect cell elongation and orientation. ${ }^{38}$ Furthermore, larger fibres have been shown to increase porosity, effecting cell infiltration and integration. ${ }^{17,39,40}$ Moreover, fibre topography (the surface structure of individual fibre) has also been highlighted to alter cellular responses in vitro. Nanotopographical features such as grooves, pores, pillars, patterns can significantly alter the adhesion, proliferation, motility, and orientation of cells compared to a smooth surface. ${ }^{41-47}$ Studies on cell responses have indicated different cell adhesion ability and function on nano/microtopographic featured scaffolds compared to smooth. ${ }^{27,48-50}$ These cellular responses to topography are highly dependent on cell type, pattern geometry and pattern size. One of these studies has worked with primary hepatocyte investigating cell spreading, adhesion and proliferation on fibres with surface pores. ${ }^{27,50}$ Interestingly, this study found that the primary hepatocyte on fibres with pores $(270 \mathrm{~nm})$ displayed more hepatic like function, such as albumin secretion. $^{27}$

These studies highlight that surface topography on polymer scaffold is a critical feature which can alter cell adhesion, proliferation and gene expression. However, to date, the influence of fibre surface depression topographies on hepatic cellular behaviour hasn't been well documented. Therefore, the purpose of our study was to investigate the effects of fibrous topographic depressions on liver cells. In this paper, PCL fibres with surface depression were prepared by using binary/ternary solvent system, and compared with large depressions, small depressions and smooth surface on hepatocyte. The hepatic cellular behaviour was investigated on these scaffold systems.

\section{Materials and methods}

\subsection{Scaffold fabrication}

Electrospun mats were fabricated by the IME technology EC-DIG electrospinning system. PCL pellets with an average molecular weight $M_{\mathrm{n}}$ of $80000 \mathrm{Da}$ (Sigma Aldrich) were dissolved in different solvent systems with overnight agitation at room temperature. The polymer solution was then poured into a $10 \mathrm{ml}$ syringe with a $0.8 \mathrm{~mm}$ diameter needle. All fibres were collected by a rotating mandrel (diameter $=8 \mathrm{~cm}$ ) covered with a non-stick aluminium foil at room temperature. Mandrel rotating speed was set to $250 \mathrm{rpm}$, and the distance between needle and mandrel was set to $24 \mathrm{~cm}$.

The nanoscale surface depressions were fabricated using systems consisting of solvent (chloroform ( $\mathrm{CFM}, \mathrm{CHCl}_{3}, \geq 99 \%$ ) and methanol $\left.\left(\mathrm{MeOH}, \mathrm{CH}_{3} \mathrm{OH}, \geq 99 \%\right)\right)$ and non-solvent (dimethylsulfoxide (DMSO)) at a ratio of 9:1 (Table 1). Large surface depression (LSD) fibre was produced by using $16 \% \mathrm{w} / \mathrm{v}$ PCL in CFM and MeOH/DMSO (5:1) solution system. Small surface depression (SSD) fibre was produced by using $14 \% \mathrm{w} / \mathrm{v}$ PCL/CFM/DMSO solution system. The no surface depression (NSD) fibre was produced by dissolving 16\% w/v PCL into CFM/ $\mathrm{MeOH}(5: 1)$ solvent. All scaffolds were dried in the hood for two days to allow the removal of residual solvent and then were punched to $10 \mathrm{~mm}$ disks.

\subsection{Scaffold sterilisation}

All scaffolds were sterilized in $70 \%$ ethanol for 30 minutes, then rinsed three times in sterile phosphate-buffered saline (PBS). Then they were freeze-dried overnight under a vacuum before plasma treatment. Scaffolds were plasma coated for 30 seconds using a Harrick Plasma cleaner (PPC-FMG-2, Harrick Plasma). Oxygen plasma treatment was used to increase the hydrophilicity of the scaffold surface and improve the cell attachment by introducing polar functional groups on to the materials without changing the bulk properties, additionally, this process can further clean the organic contaminations on the scaffolds. ${ }^{51} \mathrm{~A}$ previously described protocol was used to achieve plasma treatment. $^{52,53}$ After plasma treatment, the scaffolds were immediately immersed into a PBS solution contains $1 \% \mathrm{v} / \mathrm{v}$ antibiotic/antimycotic for one hour before changing to cell culture media overnight before seeding.

\subsection{Mechanical testing}

The scaffold samples were cut with a knife into rectangles with a gauge length of $20 \mathrm{~mm}$ and a width of $5 \mathrm{~mm}$. Thickness averages ranged from $0.09 \mathrm{~mm}, 0.12 \mathrm{~mm}$ and $0.13 \mathrm{~mm}$ for the LSD, SSD and NSD respectively. Ultimate strength and incremental Young's modulus were employed to compare the variations of mechanical behaviour of the samples. All the samples ( $n=5$ for each group) were subjected to monotonic tensile loading at a strain rate of $50 \% \varepsilon \mathrm{min}^{-1}$ to failure by using Instron material testing machine (Model 3367, 50N load cell). The incremental Young's moduli were taken at five different strain ranges: $0-5,5-15,15-25$ and $25-35 \% \varepsilon$.

\subsection{Scanning electron microscopy (SEM)}

A Hitach TM4000 SEM with $15 \mathrm{kV}$ accelerating voltage was used to characterize the samples morphology at low magnification $(\times 5000)$ and high magnification $(\times 15000)$. All scaffolds were coated by gold-palladium using an Emscope SC500A splutter coater before SEM to increase the electrical conductivity. The depressions size was determined by ImageJ software. The diameter of depressions was taken from the cross-section of each depression and each sample was measured 20 times.

Table 1 Solvent system for each type of scaffold and electrospinning parameters

\begin{tabular}{|c|c|c|c|c|c|c|c|c|c|}
\hline Scaffolds & Solvent & Non-solvent & $\begin{array}{l}\text { Solvent/non-solvent } \\
\text { ratio }\end{array}$ & PCL w/v (\%) & $\begin{array}{l}\text { Needle } \\
\text { diameter }(\mathrm{mm})\end{array}$ & $\begin{array}{l}\text { Flow rate } \\
\left(\mathrm{ml} \mathrm{h}^{-1}\right)\end{array}$ & $\begin{array}{l}\text { Mandrel } \\
\text { rotation (rpm) }\end{array}$ & $\begin{array}{l}\text { Voltage } \\
(\mathrm{kV})\end{array}$ & $\begin{array}{l}\text { Mandrel:needle } \\
\text { distance }(\mathrm{cm})\end{array}$ \\
\hline LSD & CFM: MeOH $5: 1$ & DMSO & $9: 1$ & 16 & 0.8 & 4 & 250 & $+14 /-4$ & 23 \\
\hline SSD & CFM & DMSO & $9: 1$ & 14 & 0.8 & 4 & 250 & $+14 /-4$ & 23 \\
\hline
\end{tabular}


SEM of osmium stained (cell-seeded) scaffolds was prepared by fixing samples in $4 \%$ glutaraldehyde overnight. Then they were incubated in $0.1 \%$ osmium in deionised water for 30 minutes. After that, samples were rinsed 4 times in deionised water for 1 minute each and then rinsed in 30\%, 50\%, 70\%, 90\% and $100 \%$ ethanol for 30 seconds. Then all samples were placed in hexamethyldisilazane (HMDS) for 1 minute before placing into fresh HMDS for dehydration. All scaffolds were left to dry overnight in a fume cupboard before imaging.

\subsection{HepG2 cell culture and seeding}

HepG2 cells were cultured $\left(37^{\circ}, 5 \% \mathrm{CO}_{2}\right)$ in T75 flasks with an Eagle's minimum essential media (MEM) supplemented with 1\% L-glutamine, 1\% antibiotic-antimycotic, 10\% foetal bovine serum and grown to $80 \%$ confluence. HepG2 cells were detached using Trypsin-EDTA and counted using the trypan blue exclusion method. Sterile scaffolds were removed from media and placed into 24-well cell culture plates and rinsed three times with PBS for 10 minutes each. The cell suspension was seeded onto each scaffold $\left(4.4 \times 10^{4}\right.$ cells in $20 \mu \mathrm{l}$ media $)$ and cultured in the incubator for 3 hours to allow cell adhesion before adding $1.5 \mathrm{ml}$ of media to each well. Scaffolds were cultured for 24 hours, 7 days and 14 days with media change 2 to 3 times every week. During seeding scaffolds were not anchored down and no contraction occurred during culture.

\subsection{Cell viability assay}

Cell viability was evaluated by CellTitre-Blue (CTB) cell viability assay (Promega). The viable cells can convert a dye (resazurin) to a fluorescent end product (resorufin), while nonviable cells rapidly lose their metabolic capacity thus cannot produce fluorescent signals. ${ }^{54}$ Scaffolds were placed into new 24-well

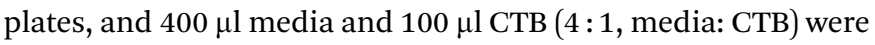
added directly to each scaffold and incubated $\left(37^{\circ}, 5 \% \mathrm{CO}_{2}\right)$ for 3 hours covered with aluminium foil to protect samples from light. After $100 \mu \mathrm{l}$ of each solution was placed into a black well plate and fluorescent signal was read using a Modulus ${ }^{\mathrm{TM}}$ II microplate reader at $560_{\mathrm{Ex}} / 590_{\mathrm{Em}} \mathrm{nm}$ (green filter) (Quant DNA-BR) for each group $(n=5)$. A negative control without cells was used to determine background fluorescence.

\subsection{DNA quantification}

Scaffolds were freeze-dried overnight before being placed in papain digest solution which contains 2.5 units per ml papain, $5 \mathrm{mM}$ cysteine, $5 \mathrm{mM}$ ethylenediaminetetraacetic (EDTA) in DNase-free distilled water. Followed by overnight oven treatment at $65{ }^{\circ} \mathrm{C}$ and periodic mixing using a vortexer. The total DNA content of the samples was analysed using Quant-iT ${ }^{\mathrm{TM}}$ PicoGreen $^{\mathrm{TM}}$ double-stranded DNA (dsDNA) assay kit (ThermoFisher, UK), according to the manufactures' protocol. This method is a fluorometric measurement of nucleic acids which is highly selective to dsDNA over RNA. Fluorescence was read using the Modulus $^{\mathrm{TM}}$ II microplate reader (excitation wavelength $\mathrm{Ex}_{\mathrm{x}}=$ $480 \mathrm{~nm}$, emission wavelength $\left.{ }_{\mathrm{Em}}=510-570 \mathrm{~nm}\right)$ for each group $(n=5)$.

\subsection{Scaffold staining}

Fluorescent imaging scaffolds were washed three times with PBS for 10 minutes each and fixed with $10 \%$ formalin. After fixation for one night, the scaffolds were washed three times with PBS and stored at $4{ }^{\circ} \mathrm{C}$ before staining. Scaffolds were permeabilised with $0.2 \%$ Triton X-100 solution for 10 minutes before washing 3 times with PBS for 10 minutes each. Samples were stained with $1000 \times$ Phalloidin-iFluorTM514 conjugate in PBS with $1 \%$ bovine serum albumin $(1: 1000)$ for 30 minutes at room temperature (plate wrapped in foil). Then the scaffolds were washed 3 times with PBS for 10 minutes each. Samples were then stained with $4^{\prime}$,6-diamidino-2-phenylindole (DAPI) for 15 minutes at room temperature (plate wrapped in foil), then rinsed 3 times with PBS for 10 minutes each. Stained samples were stored in PBS and kept in the fridge wrapped in foil before being transferred to glass slides for imaging.

\subsection{Gene expression analysis}

RNA was extracted from scaffolds using a Trizol (Fisher Scientific) method and stored at $-80{ }^{\circ} \mathrm{C}$ before preparing complementary DNA (cDNA) [2]. The cDNA was prepared according to the Promega InProm-II Reverse Transcription kit protocol. Quantitative real-time polymerase chain reaction (qRT-PCR) was performed using the LightCycler ${ }^{\circledR} 480$ Instrument II (Roche Life Science) and Sensifast ${ }^{\mathrm{TM}} \mathrm{SYBR}^{\circledR}$ High-ROX (Bioline) system. Results were compared to the housekeeping gene Glyceraldehyde-3-Phosphate Dehydrogenase (GAPDH) to normalise the gene expression level. Controls for gene expression were respective HepG2 cells cultured on a cell culture plate for 24 hours. The $2-\Delta \Delta \mathrm{Ct} \operatorname{method}^{4,55}$ was used to analyse the relative mRNA levels of albumin, collagen I alpha 1 (Col1A1) and Cytochrome P450 Family 3 Subfamily A Polypeptide 4 (cyp3A4), $n=5$.

\subsection{Statistical analysis}

Statistics analyse was performed using one-way ANOVA and Tukey post hoc test with Minitab 18 software, the difference is considered statistically significant with $p$-values of $<0.05^{*}$ and $<0.01^{* *}$. Error bars indicate standard deviations. All results were expressed as mean \pm standard deviation.

\section{Results}

\subsection{Scaffold characterisation}

PCL fibre mats were punched to small discs with a $10 \mathrm{~mm}$ diameter and their SEM images were shown accordingly in Fig. 1. It is clear that the samples with different depressions have different architectures. The cross-section images show the solid interior without internal pores on all samples. The size of fibre diameter and depressions were determined by using ImageJ software analysis of the SEM images. Notably, the same fibre size was maintained for samples with different depressions. The fibre diameters only had a $4 \%$ difference between the groups. The diameters of LSD and SSD were $2.14 \pm 0.62 \mu \mathrm{m}$ and $0.37 \pm 0.10 \mu \mathrm{m}$, respectively (Table 2). 


\section{A}
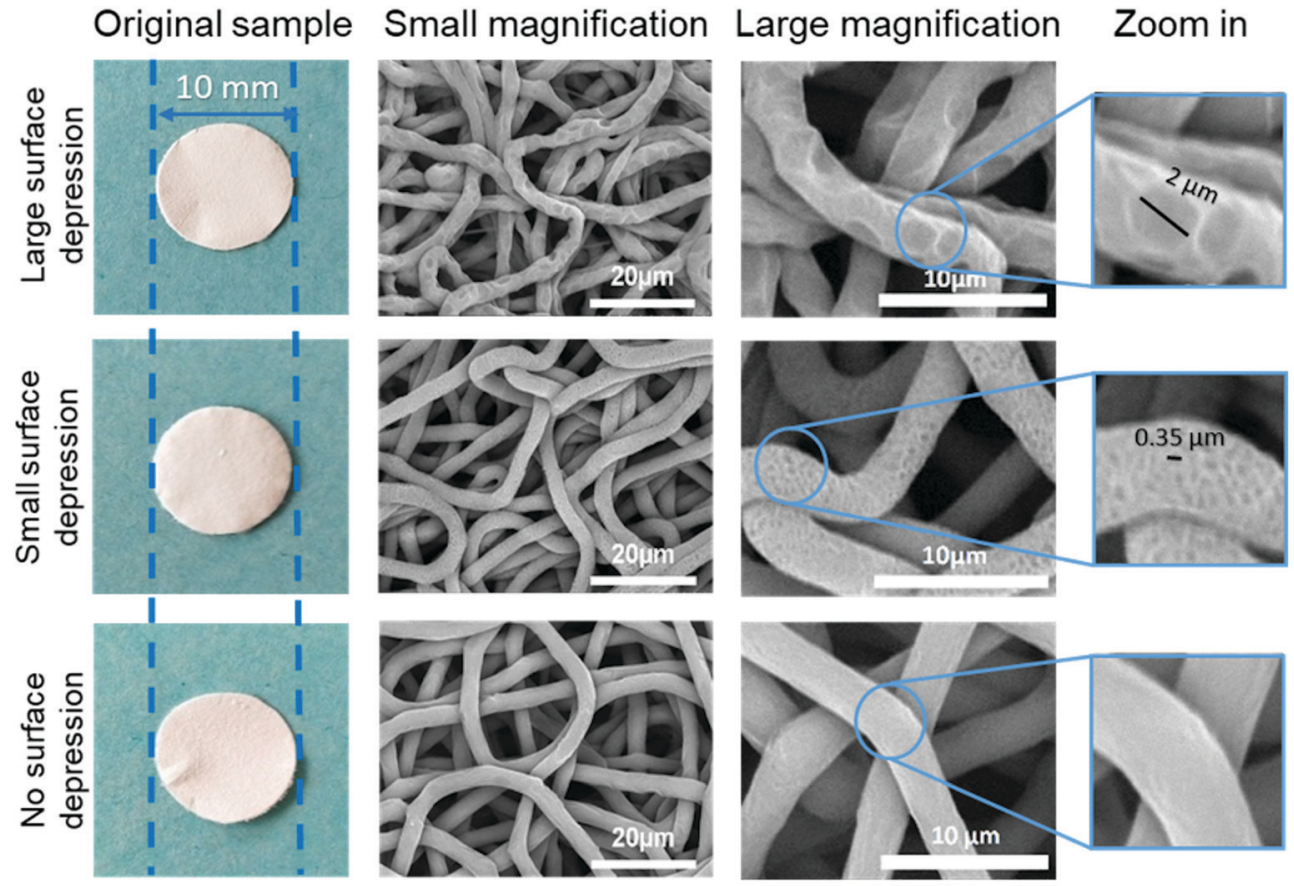

$\mathrm{B}$

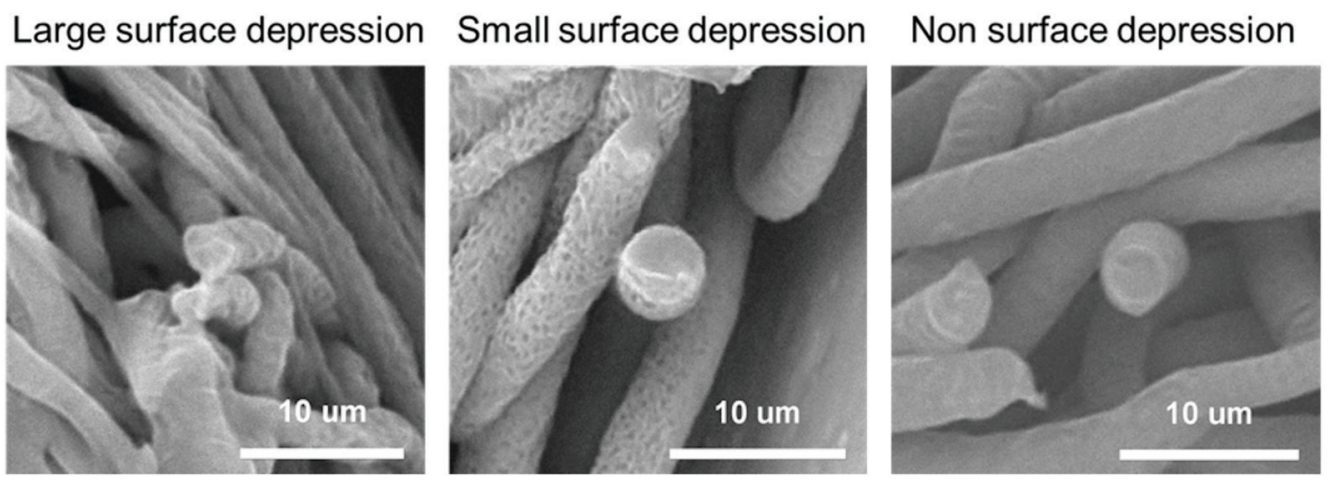

Fig. 1 SEM images of electrospun fibres show the PCL scaffolds with different surface topographical features (A); the cross-section SEM images of large, small and no surface depression fibres (B).

The evaluated mechanical properties of the manufactured scaffolds are shown in Table 2. Tensile properties were altered by the changing of depressions which was achieved by the addition of a non-solvent (DMSO). For both the LSD and SSD the ultimate tensile strength and Young's modulus were significantly larger than the NSD (Fig. 2). Furthermore, only small differences in ultimate tensile strain and Young's modulus are noted between the SSD and LSD (Table 2). Notably, the SSD has the highest Young's modulus compared with other groups and this was apparent for all the strain ranges examined.

\subsection{Cell viability and DNA quantification}

Fig. 3A shows the cell viability, with the LSD group significantly lower than the other two groups. The cell viability of SSD kept increasing from 24 hours to 14 days, however, the other two groups were increased at 7 days but dropped after 14 days. Although the cell viability of NSD group was slightly higher than SSD group on day 7, it becomes lower after 14 days of culture. Additionally the LSD significantly different to the SSD and NSD groups on day 7 and 14 .

DNA quantification shows similar results to cell viability (Fig. 3B). DNA content per cell is absolute, therefore indicating the cell number per scaffold so that we can understand the cell attachment and proliferation. ${ }^{39,56}$ All groups showed an upward trend on day 7 compared to 24 hours, while the SSD and NSD groups showed a slight decrease on day 14. Moreover the SSD group shows the highest DNA content on days 7 and 14 . There are significant differences between the SSD and NSD groups between 24 hours and day 14. Furthermore, the SSD and LSD groups also have a significant difference on both day 7 and 14. Cell viability was normalized to DNA content, as shown in Fig. 3C. No significant difference is observed when comparing between scaffold groups within the same time point. However a consistent reduction is observed across all scaffold groups 
Table 2 Physical properties and mechanical properties of the PCL scaffolds

\begin{tabular}{lllll}
\hline & Strain range (\%) & Large surface depression & Small surface depression & No surface depression \\
\hline Fibre diameter $(\mu \mathrm{m})$ & - & $3.03 \pm 0.32$ & $3.10 \pm 0.29$ & $3.14 \pm 0.28$ \\
Depression diameter $(\mu \mathrm{m})$ & - & $2.14 \pm 0.62$ & $0.37 \pm 0.10$ & N/A \\
Thickness of disc $(\mathrm{mm})$ & - & $0.09 \pm 0.02$ & $0.12 \pm 0.01$ & $0.13 \pm 0.01$ \\
Ultimate tensile strength $(\mathrm{MPa})$ & - & $1.54 \pm 0.17$ & $1.67 \pm 0.26$ & $0.81 \pm 0.09$ \\
Rapture strain $(\% \varepsilon)$ & - & $585.72 \pm 16.63$ & $568.9 \pm 54.07$ & $766.36 \pm 42.6$ \\
Young's modulus (MPa) & $0-5$ & $5.56 \pm 0.56$ & $6 \pm 1.25$ & $2.83 \pm 0.42$ \\
& $5-15$ & $1.55 \pm 0.33$ & $1.95 \pm 0.44$ & $0.74 \pm 0.09$ \\
& $15-25$ & $0.7 \pm 0.17$ & $0.85 \pm 0.15$ & $0.36 \pm 0.08$ \\
& $25-35$ & $0.45 \pm 0.04$ & $0.58 \pm 0.16$ & $0.22 \pm 0.07$ \\
\end{tabular}

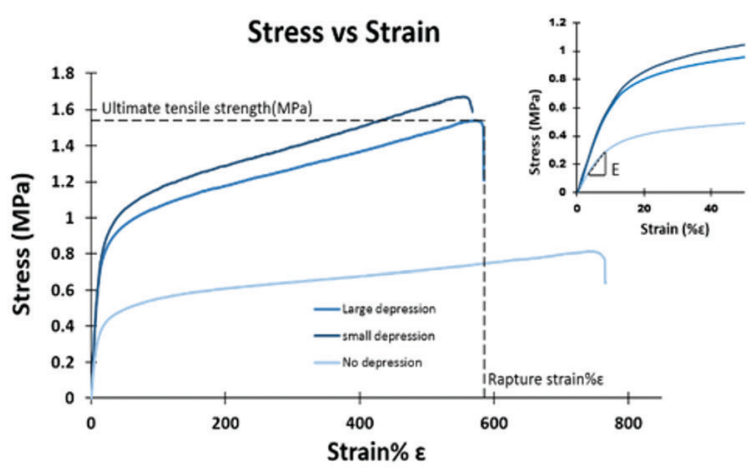

(a)

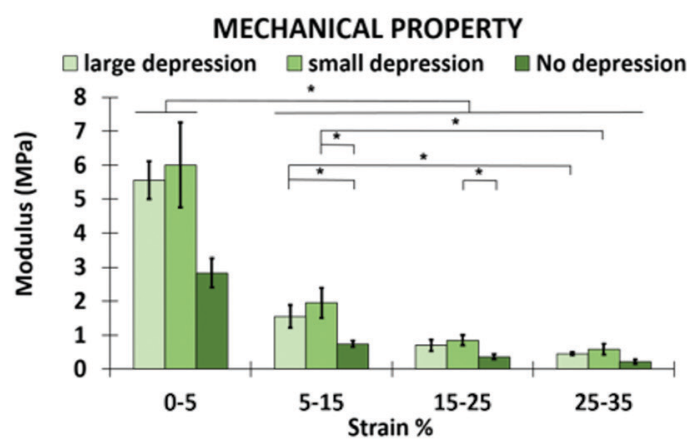

(b)

Fig. 2 Stress versus strain curve (a) and Young's modulus (b) of each scaffold sample, measured by tensile testing.

(A)

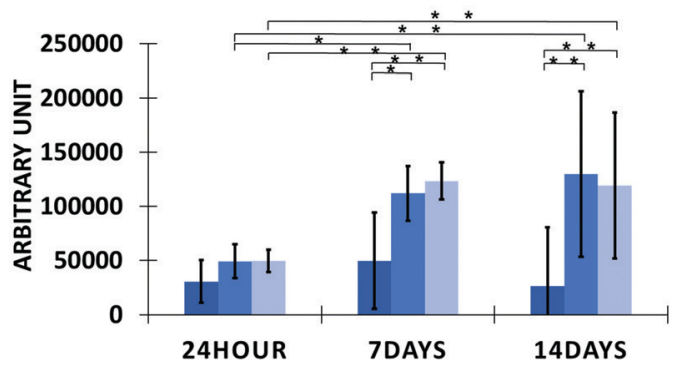

(B)

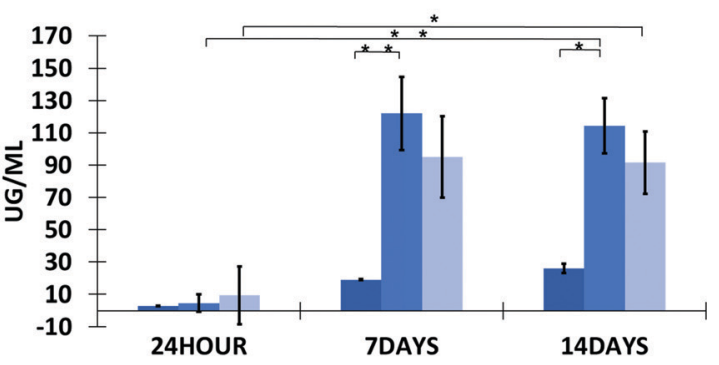

(C) Cell viability normalized to DNA content

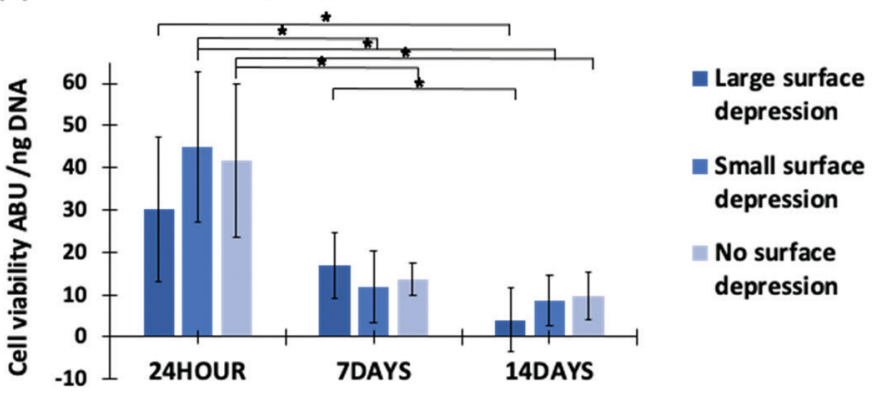

Fig. 3 (A) Cell viability results for HepG2 on separate scaffold groups, measured via Cell Titre Blue assay. (B) HepG2 dsDNA quantity, measured via Picogreen assay, $N=5$, error bars \pm SD. (C) Cell viability normalized to DNA content. Statistics performed: one-way ANOVA Tukey post hoc test, ${ }^{*}=p$ value $<0.05,{ }^{* *}=p$ value $<0.01$ 
when comparing across time points. The reduction is statistically significant when comparing between 24 hours and day 7 for SSD and NSD and statistically significant for all groups when comparing between 24 hours and day 14 .

\subsection{Gene expression of HepG2 cells}

Q-PCR results show the regulations in the expression of liver genes, albumin, collagen $1 \mathrm{~A} 1$ and Cytochrome P450 3A4 (Cyp3A4) (Fig. 4). Fig. 4A shows all groups have an upregulation at 24 hours and day 14, and a much higher gene expression level at day 14. However, lower gene expression for large depression and no depression groups at day 7 compared to the other time points, even a downregulation shown in the SSD group. There is a significant difference between 24 hours and 14 days in the NSD group. The collagen 1A1 gene level of all groups was upregulated at 24 hours and days 7 , however, the NSD group had a downregulation in expression at day 14. Downregulation of CYP3A4 was noted for all three scaffolds between 24 hour and 14 days. Conversely, all three scaffold types displayed relatively similar gene expression trends.

\subsection{Cell morphology on each type of scaffold}

HepG2 cells had different reactions on each type of scaffold (Fig. 5). There is no noticeable difference in the images between all groups in 24 hours. Cells spreading is notable on day 7 on the SSD and NSD scaffolds, and they tended to form a monolayer at day 14. In contrast, the LSD scaffold shows very poor cell attachment on days 7 and 14, which in part matches the cell viability and DNA quantification results.

Representative DAPI and Phalloidin fluorescence staining images (Fig. 6) of the scaffolds revealed cell attached at all-time points. The qualitative assessment indicates that the SSD and NSD had larger amounts attached and abundant fibronectin production on day 14 compared to the LSD group.

\section{Discussion}

Electrospun cell scaffolds have been highlighted in liver tissue engineering with some studies using PCL due to its good biocompatibility. ${ }^{57,58}$ Although PCL is a hydrophobic material, plasma coating can significantly improve its hydrophilicity, thus improving cell attachment. ${ }^{38,59}$ More recently alteration to the nanotopography of electrospun fibre architecture has shown potential in tissue engineering applications. ${ }^{60,61}$ One method to achieve this is through vapour induced phase separation which can effectively generate surface structures. ${ }^{62,63}$ Another method to achieve this is through non-solvent induce phase separation, a technique that can drive the formation of topographical depressions. ${ }^{64-67}$ This technique has produced fibres with surface depressions ranging between $0.1-0.8 \mu \mathrm{m}$, using a DMSO system. ${ }^{68}$ In this study, we successfully used DMSO and achieved a depression range of $0.37-2.14 \mu \mathrm{m}$ (Table 2). Controlling this formation process allows unique surface features to be created as highlighted in the SEM images (Fig. 1).

The manufacture method presented in this article for the depression fibres is based on solvent/non-solvent systems. ${ }^{65}$ In our case we take advantage of the miscibility of polymers in solvents, specifically PCL is dissolvable in CFM, while only partially in $\mathrm{MeOH}$ and completely insoluble DMSO. ${ }^{69} \mathrm{MeOH}$ and DMSO have relatively higher dielectric constant than CFM with values of $32.6,46.7$ and 4.8 respectively, giving them a larger electrostatic field, which supports stable jet formation. ${ }^{69}$ However, during the spinning process, because of the high boiling point of DMSO $\left(189{ }^{\circ} \mathrm{C}\right)$, which is three times higher than CFM $\left(61{ }^{\circ} \mathrm{C}\right)$ and $\mathrm{MeOH}\left(64.7^{\circ} \mathrm{C}\right)$, these two solvents will evaporate from the fibres, before the solvent/non-solvent ratio changes and phase separation occurs. ${ }^{70}$ The remaining DMSO forms droplets on the fibre surface, where the small depression appears after complete drying. In the CFM/MeOH/DMSO

\section{$\square 24 \mathrm{Hrs} \quad \square 7$ Days $\quad \mathbf{1 4}$ Days}

ALBUMIN

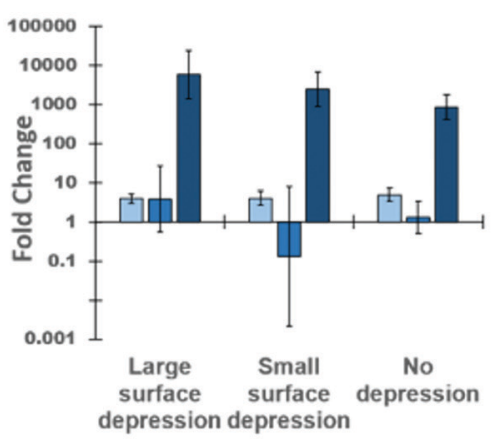

(A)
COLLAGEN 1A1

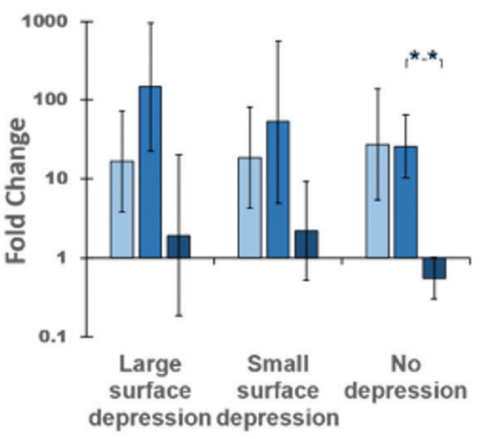

(B)
CYP3A4

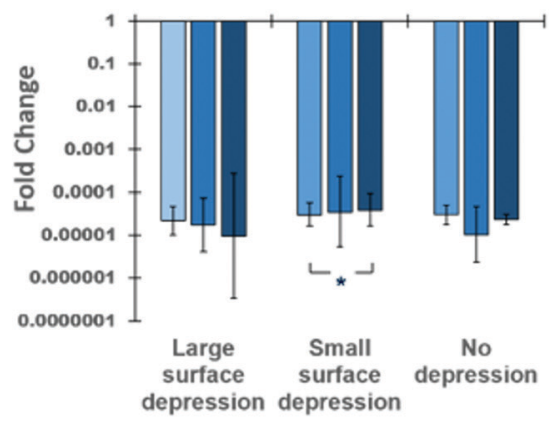

(C)

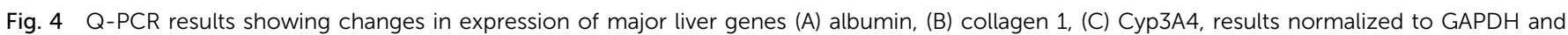
relative to tissue culture plates. Statistics performed: one-way ANOVA Tukey post hoc test, * $=p$ value $<0.05,{ }^{\star}=p$ value $<0.01$. 
A
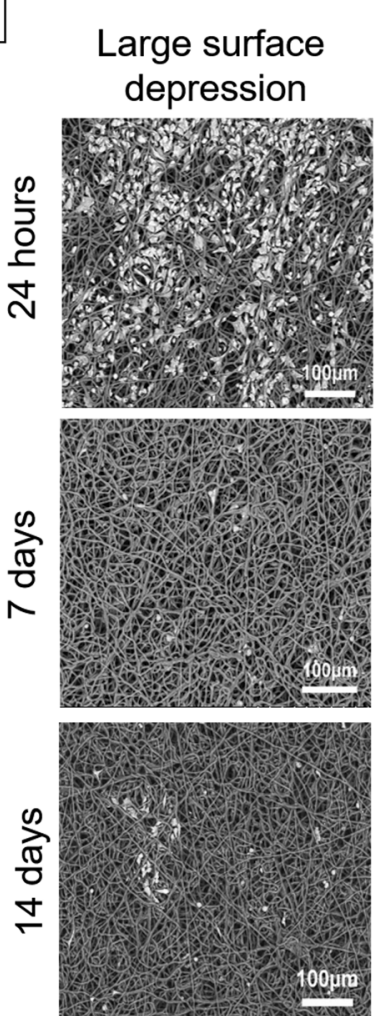

B
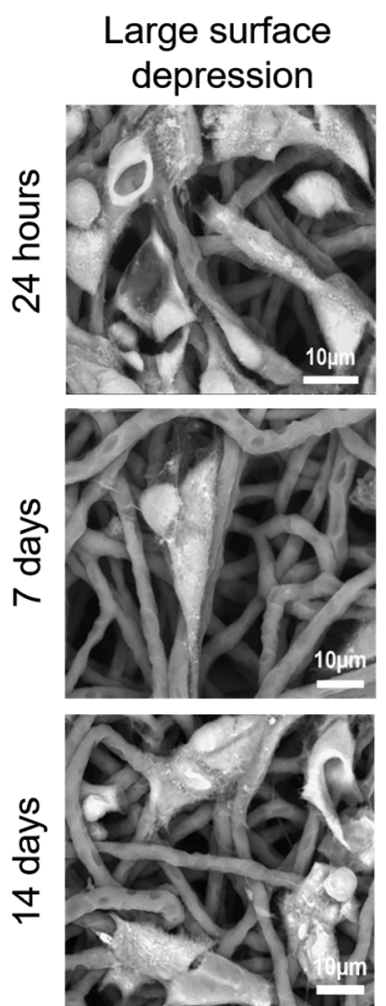
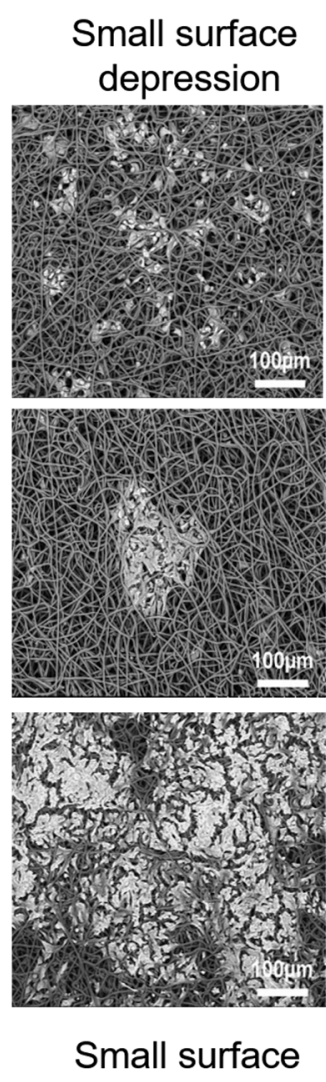
depression
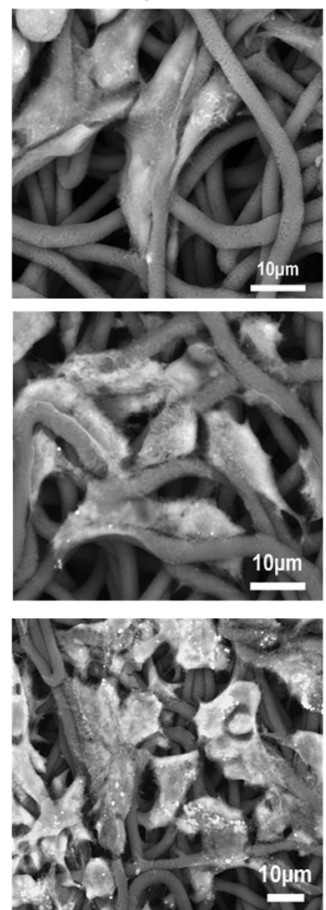

Non surface

depression
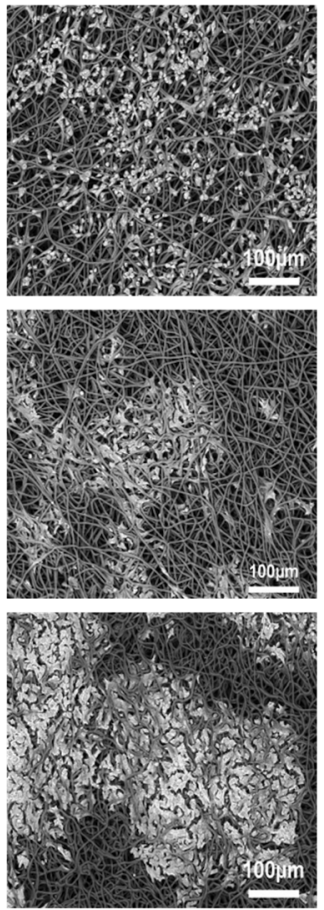

Non surface depression
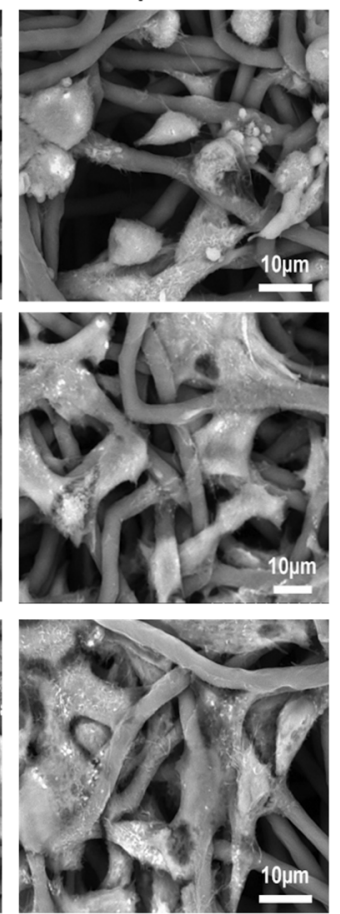

Fig. 5 Osmium staining scaffolds at time points of 24 hours, 7 days and 14 days (small magnification and big magnification).

solvent system, as $\mathrm{MeOH}$ and DMSO are miscible with each other along with water, this allows the moisture from the air to mix with them (water is non-solvent for PCL), and therefore spread on the surface of the fibre leading to large depressions being formed. ${ }^{70}$ This allows us to create a distinctive set of controlled fibre variations. 

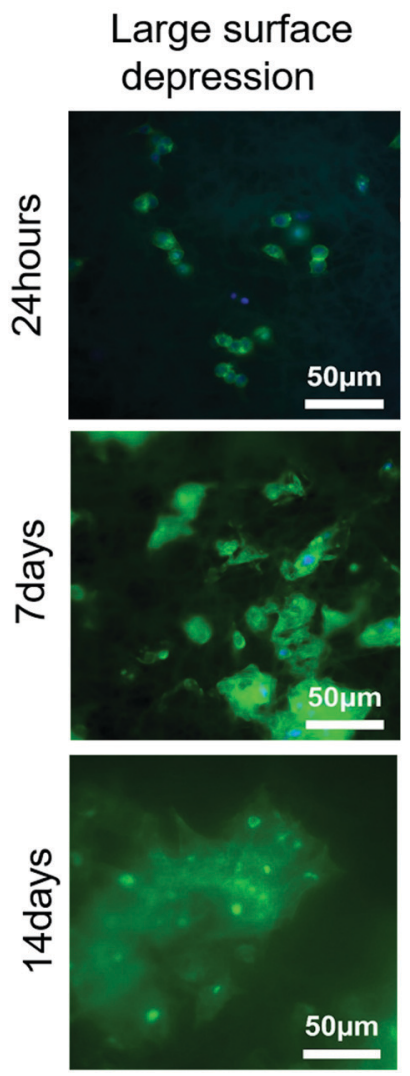
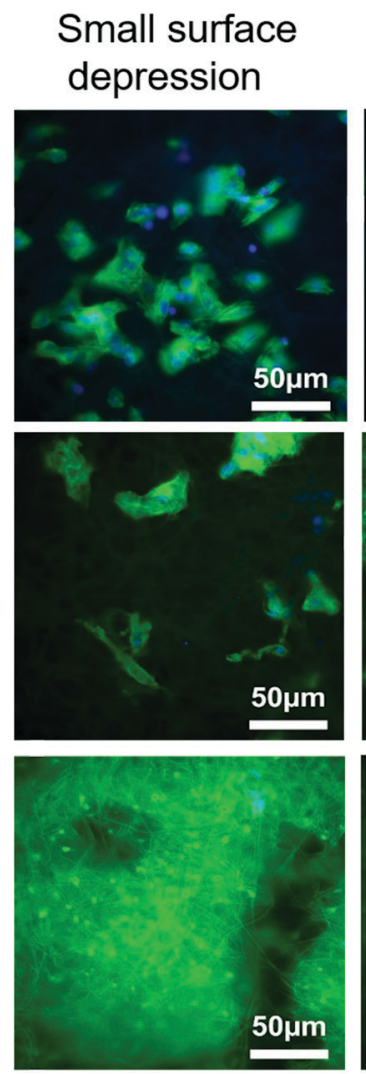

No surface depression
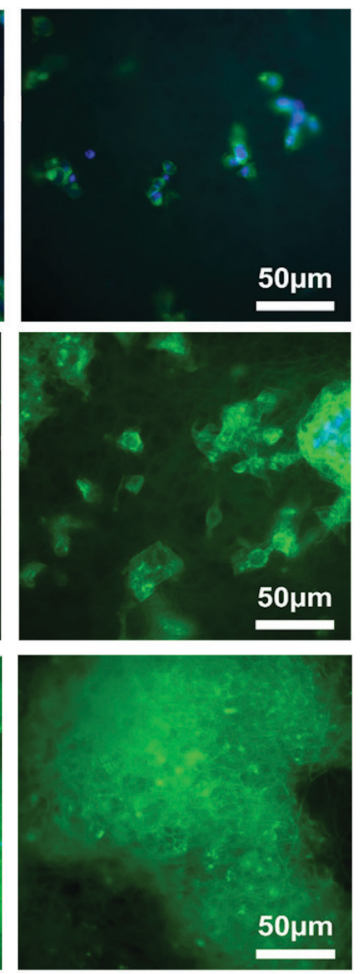

Fig. 6 DAPI (blue $=$ cell nuclei) and phalloidin (green = actin filaments) staining of HepG2 cultures attached to the separate scaffold groups .

The mechanical properties of a scaffold structure play a role in cellular performances. Our finding show that the mechanical properties were significantly altered by the addition of the nonsolvent. As shown in the results (Table 2), the ultimate tensile strength and Young's modulus of depression samples were significantly increased than non-depression samples, similar results can be seen in a previous study. ${ }^{71}$ It was explained by the crystallization process of the polymer and the orientation of molecular chains. ${ }^{72}$ PCL is the semi-crystalline polymer that consists of soft phase and hard phase, which is related to the amorphous phase and crystalline phase. ${ }^{73,74}$ The polymer jet can be stretched to a greater extent due to the higher dielectric constant of DMSO $(\varepsilon=46.7)$. A greater crystalline region and a higher orientation of macromolecular chains formed in the depression samples can be partly attributed to the enhanced tensile properties of fibres. ${ }^{72,75}$

The addition of surface features on electrospun fibres has been widely shown to influence cellular activities in vitro. ${ }^{60,61,76}$ Herein we have revealed a similar outcome, demonstrated by the LSD and SSD scaffolds which influenced cell viability and DNA content of HepG2 cells. This is highlighted further by the different cellular behaviours at all-time points (Fig. 3). HepG2 cells had a significantly higher survival rate (cell viability) on SSD than on the LSD scaffolds. Additionally the SSD group had a growing trend in cell viability during 14 days culture, meanwhile the other two groups both dropped on day 14. Similarly, SSD had significant higher DNA content than the LSD scaffolds at day 14
(Fig. 3B). In Fig. 3C a statistically significant reduction of the cell viability normalized to the DNA content is observed across time points. As shown in Fig. $3 \mathrm{~A}$ and $\mathrm{B}$ the increase in cell viability is smaller than the respective change in DNA content which leads to the reduction in the normalisation data. This may be expected as Cell Titre Blue is linked to metabolic activity of the cells and is only an approximation for viability. ${ }^{77,78}$ While if we consider that DNA content per cell, this should remain stable across the experimental timeline with each cell's metabolic activity being altered as a result of growth conditions. These changes are influenced by the cells' life cycle and its immediate environment resulting in the observed shift across the normalisation data. $^{79-82}$ These results are in part corroborated by the osmium stained SEM and the immunofluorescent cell-seeded scaffolds (Fig. 5 and 6). One consideration to note during osmium staining is that there is potential to lose cells, as part of the multiple washing steps, therefore some of the images may not represent the actual cell numbers. The results suggesting that changing the surface topography has a noticeable impact on hepatocyte cell performance, with SSD achieving marginally higher results to NSD.

Topography has been used previously in research to control some cell response. ${ }^{31,32}$ Interestingly, You et al. developed similar topographic features to our study, where they fabricated patterned substrates with pitches of 400, 1400 and $4000 \mathrm{~nm}$, and revealed $400 \mathrm{~nm}$ pitch pattern enhanced albumin expression and cell junction formation of primary hepatocytes. ${ }^{49}$ 
These patterns are in similar size scale to our depression features (370 and $2140 \mathrm{~nm}$ ). Also, in Wang et al.'s study, they found that nanopores of $270 \mathrm{~nm}$ on PLLA fibres result in the formation of a hepatocyte monolayer, and showed more hepatic like functions. ${ }^{27}$ These results corroborate our findings that surface topography plays an important role in hepatic cell responses. This maybe in part due to the porous features providing additional attachment points, once adhesion occurs. Notably, on the contrary Lubasová et al. investigation on primary hepatocytes indicated that survival was increased on smooth fibres, with a notable decrease on their porous type. ${ }^{50}$ These studies highlight intrinsically different responses to topographic feature types, which are in part due to cell phenotype, differentiation, source and cellular senescence, but are also influenced by the substrate base size. These parameters are extremely variable, highlighting the need to tune scaffold architecture to the individual needs of a specific cell type.

Albumin is a specific marker for liver, its level can be used to show the response of hepatocytes to a scaffold environment. ${ }^{83}$ Collagen 1A1 gene provides major instructions for the synthesis of type I collagen, its regulation is important in supporting hepatic function. ${ }^{84}$ Gene expression showed that scaffolds influenced albumin and collagen 1A1 gene expression, while CPY3A4 was not altered. Similarly, a study by Nicholas et al., ${ }^{85}$ found that fibres with surface pits could be used to alter gene expression in macrophages, which in part corroborates our findings. Notably all the presented fibre topographies seem to provide an environment where deposited HepG2 cells can maintain their typical genetic functionality while altering the growth rate.

Previous studies on similar electrospun fibres have shown that different cell types can respond in a comparable manner, and co-culture can initiate other functions. ${ }^{37,56,86,87}$ As the liver is a complex organ, a layer of liver tissue is usually composed of hepatocytes, epithelial cells, Kupffer cells, stellate cells, and liver sinusoidal endothelial cells. How to design or to use a potential scaffold depends on what function is required. In the literatures, HepG2s have been shown to be bioactive on similar types of scaffold in comparison to ours, but it is worthy to note that previous studies have also shown preference for extremely different fibre sizes. ${ }^{53,88,89}$ Besides this, co-culture has been shown to influence cell bioactivity, for example hepatocytes co-cultured with HUVECs on a multiscale fibre scaffold recapitulated a liver tissue-like structure, and significantly increased function in vitro. ${ }^{90,91}$ Therefore, tissues within an organ might require different surfaces to optimise function, especially in the liver which has numerous and varied functions. Consequently future scaffold developments with more than one cell type would require optimisation.

While our study shows some key influences on hepatic cells, they are not without shortcomings. The cell type used, HepG2 is an immortal cell line derived from hepatocellular carcinoma tissue. ${ }^{92}$ It is a commonly used liver cell as an in vitro model system for hepatotoxicity. ${ }^{4}$ This is in part due to it's virus-free nature, high proliferation rate and it's ability to perform many hepatic specific functions such as albumin secretion. ${ }^{93-95}$
However, because it is relatively stable in vitro culture, it does not give a true reflection of primary culture. Future work is needed to access primary or stem cells derived hepatocytes to verify the effect of scaffolds on long-term in vitro culture while ensuring that variables such as fibre base size and pore size are taken into count. Though for consideration is the rare accessibility of human primary cells, which would make the use of rat primary hepatocytes a stepping stone in understanding the full potential of these scaffolds. ${ }^{96}$ Additionally, aspects such as fibre orientation would need to be examined to get a true cell response.

\section{Conclusion}

Herein we successfully fabricated large and small surface depressions on electrospun scaffolds by using different solvent systems. The biological testing revealed small depression fibre had better cell viability and DNA content than the other groups. These results have shown that electrospun fibres with surface depressions could be used to control cellular reactions in HepG2 cells. This work highlights the possibilities of electrospun scaffolds at controlling hepatic function, and may have potential in the development of liver tissue-mimicking platforms.

\section{Conflicts of interest}

There are no conflicts to declare.

\section{Acknowledgements}

This work was supported by the UKRMPII Grant Ref: MR/ L022974/1 and the MRC CCBN Grant Ref: MR/L012766/1. The authors would like to acknowledge Dr David Kelly (COIL) for assisting with and facilitating the microscopy imaging and Prof. Alistair Elfick for access to the laboratory facilities (Institute for Bioengineering).

\section{References}

1 S. K. Asrani, H. Devarbhavi, J. Eaton and P. S. Kamath, Burden of liver diseases in the world, J. Hepatol., 2019, 70(1), 151-171, DOI: 10.1016/j.jhep.2018.09.014.

2 British Liver Trust, The alarming impact of liver disease in the UK, Bournemouth, 2019.

3 R. Williams, G. Alexander, I. Armstrong, A. Baker, N. Bhala, G. Camps-walsh, M. E. Cramp, S. De Lusignan, N. Day, A. Dhawan, J. Dillon, C. Drummond, J. Dyson, G. Foster, I. Gimore, M. Hudson, D. Kelly, A. Langford, N. McDougall, P. Meier, K. Moriarty, P. Newsome, J. O’Grady, R Pryke, L. Rolfe, P. Rice, H. Rutter, N. Sheron, A. Taylor, J. Thompson, D. Thorburn, J. Verne, J. Wass and A. Yeoman, Disease burden and costs from excess alcohol consumption, obesity, and viral hepatitis: fourth report of the Lancet Standing Commission on Liver Disease in the 
UK, Lancet, 2018, 391(10125), 1097-1107, DOI: 10.1016/ S0140-6736(17)32866-0.

4 R. Grant, D. Hay and A. Callanan, From scaffold to structure: the synthetic production of cell derived extracellular matrix for liver tissue engineering From scaffold to structure: the synthetic production of cell derived extracellular matrix for liver tissue engineering, Biomed. Phys. Eng. Express, 2018, 4(6), 65015, DOI: 10.1088/2057-1976/aacbe1.

5 G. Mazza, W. Al-Akkad, K. Rombouts and M. Pinzani, Liver Tissue Engineering: From Implantable Tissue to Whole Organ Engineering, Hepatol. Commun., 2018, 2(2), 131-141, DOI: 10.1002/hep4.1136.

6 Y. Li, H. Harn, D. Hsieh, T. Wen, Y. Subeq, L. Sun, S. Lin and T. Chiou, Review Cells and Materials for Liver Tissue Engineering, Cell Transplant., 2013, 22(1), 685-700, DOI: 10.3727/096368912X655163.

7 Med ST. Cell and Tissue Engineering for Liver Disease Sangeeta, 2015, 6(245), DOI: 10.1126/scitranslmed.3005975.Cell.

8 S. Kazemnejad, Hepatic Tissue Engineering Using Scaffolds: State of the Art, Avicenna J. Med. Biotechnol., 2010, 1(3), 1-11, papers3://publication/uuid/E3E0F526-68A9-4917-83F20CB25EF1A541.

9 G. Mazza, K. Rombouts, A. R. Hall, L. Urbani, T. V. Luong, W. Al-akkad, L. Longato, D. Brown, P. Maghsoudlou, A. P. Dhillon, B. Fuller, B. Davidson, K. Moore, D. Dhar, P. D. Coppi, M. Malago and M. Pinzani, Decellularized human liver as a natural 3D-scaffold for liver bioengineering and transplantation, Sci. Rep., 2015, 1-15, DOI: 10.1038/ srep13079.

10 M. He, A. Callanan, K. Lagaras, J. A. M. Steele and M. M. Stevens, Optimization of SDS exposure on preservation of ECM characteristics in whole organ decellularization of rat kidneys, J. Biomed. Mater. Res., Part B, 2017, 105(6), 1352-1360, DOI: 10.1002/jbm.b.33668.

$11 \mathrm{M}$. He and A. Callanan, Comparison of methods for wholeorgan decellularization in tissue engineering of bioartificial organs, Tissue Eng., Part B, 2013, 19(3), 194-208, DOI: 10.1089/ten.teb.2012.0340.

12 B. Dhandayuthapani, Y. Yoshida, T. Maekawa and D. S. Kumar, Polymeric scaffolds in tissue engineering application: a review, Int. J. Polym. Sci., 2011, 2011, 290602, DOI: 10.1155/2011/290602.

13 N. Munir, A. McDonald and A. Callanan, A combinatorial approach: Cryo-printing and electrospinning hybrid scaffolds for cartilage tissue engineering, Bioprinting, 2019, 16, e00056, DOI: 10.1016/j.bprint.2019.e00056.

14 A. Sturtivant and A. Callanan, The use of Antifreeze Proteins to modify pore structure, in directionally frozen alginate sponges, for cartilage tissue engineering, Biomed. Phys. Eng. Express, 2020, 6(5), 055016, DOI: 10.1088/2057-1976/aba7aa.

15 N. Bhardwaj and S. C. Kundu, Electrospinning: A fascinating fiber fabrication technique, Biotechnol. Adv., 2010, 28(3), 325-347, DOI: 10.1016/j.biotechadv.2010.01.004.

16 S. Kazemnejad, A. Allameh, M. Soleimani, A. Gharehbaghian, N. Amirizadeh, S. Kaviani, M. Jazayeri and M. Amani, Development of a Novel Three-Dimensional Biocompatible
Nanofibrous Scaffold for the Expansion and Hepatogenic Differentiation of Human Bone Marrow Mesenchymal Stem Cells. Iranian, J. Biotechnol., 2007, 5(4), 201-211.

17 T. S. R. Bate, S. J. Forbes and A. Callanan, Controlling electrospun polymer morphology for tissue engineering demonstrated using hepG2 cell line, J. Visualized Exp., 2020, 2020(159), 1-9, DOI: 10.3791/61043.

18 S. Chung, C. Gentilini, A. Callanan, M. Hedegaard, S. Hassing and M. M. Stevens, Responsive poly ( $\gamma$-glutamic acid) fibres for biomedical applications, J. Mater. Chem. B, 2013, 1(10), 1397-1401, DOI: 10.1039/c3tb00515a.

19 Q. Zhou, J. Xie, M. Bao, H. Yuan, Z. Ye, X. Lou and Y. Zhang, Engineering aligned electrospun PLLA microfibers with nano-porous surface nanotopography for modulating the responses of vascular smooth muscle cells, J. Mater. Chem. B, 2015, 3(21), 4439-4450, DOI: 10.1039/c5tb00051c.

20 M. Zhang, X. Zhao, G. Zhang, G. Wei and Z. Su, Electrospinning design of functional nanostructures for biosensor applications, J. Mater. Chem. B, 2017, 5(9), 1699-1711, DOI: 10.1039/c6tb03121h.

21 K. Dziemidowicz, Q. Sang, J. Wu, Z. Zhang, F. Zhou, J. M. Lagaron, X. Mo, G. J. M. Parker, D. G. Yu and L. M. Zhu, et al., Electrospinning for healthcare: recent advancements, J. Mater. Chem. B, 2021, 9(4), 939-951, DOI: 10.1039/d0tb02124e.

22 S. Y. Severt, S. L. Maxwell, J. S. Bontrager, J. M. Leger and A. R. Murphy, Mimicking muscle fiber structure and function through electromechanical actuation of electrospun silk fiber bundles, J. Mater. Chem. B, 2017, 5(40), 8105-8114, DOI: 10.1039/c7tb01904a.

23 W. Gao, L. Sun, X. Fu, Z. Lin, W. Xie, W. Zhang, F. Zhao and $\mathrm{X}$. Chen, Enhanced diabetic wound healing by electrospun core-sheath fibers loaded with dimethyloxalylglycine, J. Mater. Chem. B, 2018, 6(2), 277-288, DOI: 10.1039/ c7tb02342a.

24 S. Chen, J. V. John, A. McCarthy and J. Xie, New forms of electrospun nanofiber materials for biomedical applications, J. Mater. Chem. B, 2020, 8(17), 3733-3746, DOI: 10.1039/d0tb00271b.

25 S. Georgiadou, K. A. G. Katsogiannis and G. T. Vladisavljevic, Porous electrospun polycaprolactone (PCL) fibres by phase separation, Eur. Polym. J., 2015, 69, 284-295, DOI: 10.1016/j.eurpolymj.2015.01.028.

26 J. A. Reid, K. D. Dwyer, P. R. Schmitt, A. H. Soepriatna, K. L. Coulombe and A. Callanan, Architected fibrous scaffolds for engineering anisotropic tissues, Biofabrication, 2021, 13(4), 045007, DOI: 10.1088/1758-5090/ac0fc9.

27 T. Wang, Z. Q. Feng, M. K. Leach, J. Wu and Q. Jiang, Nanoporous fibers of type-I collagen coated poly(L-lactic acid) for enhancing primary hepatocyte growth and function, J. Mater. Chem. B, 2013, 1(3), 339-346, DOI: 10.1039/ c2tb00195k.

28 J. A. Terrell, C. G. Jones, G. Keza, M. Kabandana and C. Chen, From cells-on-a-chip to organs-on-a-chip: scaffolding materials for 3D cell culture in microfluidics, J. Mater. Chem. B, 2020, 8, 6667, DOI: 10.1039/d0tb00718h. 
29 T. Huang, C. G. Jones, J. H. Chung and C. Chen, Microfibrous Extracellular Matrix Changes the Liver Hepatocyte Energy Metabolism via Integrins, ACS Biomater. Sci. Eng., 2020, 6(10), 5849-5856, DOI: 10.1021/acsbiomaterials.0c01311.

30 X. Liu, L. Zhou, P. Heng, J. Xiao, J. Lv, Q. Zhang, M. E. Hickey, Q. Tu and J. Wang, Lecithin doped electrospun poly(lactic acid)-thermoplastic polyurethane fibers for hepatocyte viability improvement, Colloids Surf., B, 2019, 175, 264-271, DOI: 10.1016/j.colsurfb.2018.09.069.

31 M. Hatamzadeh, R. Sarvari, B. Massoumi, S. Agbolaghi and F. Samadian, Liver tissue engineering via hyperbranched polypyrrole scaffolds, Int. J. Polym. Mater. Polym. Biomater., 2020, 69(17), 1112-1122, DOI: 10.1080/00914037.2019.1667800.

32 R. Grant, J. Hallett, S. Forbes, D. Hay and A. Callanan, Blended electrospinning with human liver extracellular matrix for engineering new hepatic microenvironments, Sci. Rep., 2019, 9(1), 6293, DOI: 10.1038/s41598-019-42627-7.

33 P. Das, M. D. DiVito, J. A. Wertheim and L. P. Tan, CollagenI and fibronectin modified three-dimensional electrospun PLGA scaffolds for long-term in vitro maintenance of functional hepatocytes, Mater. Sci. Eng., C, 2020, 111, DOI: 10.1016/j.msec.2020.110723.

34 J. Zhang, Y. T. Zhao, P. Y. Hu, J. J. Liu, X. F. Liu, M. Hu, Z. Cui, N. Wang, Z. Niu and H. F. Xiang, et al., Laparoscopic electrospinning for in situ hemostasis in minimally invasive operation, Chem. Eng. J., 2020, 395, 125089, DOI: 10.1016/ j.cej.2020.125089.

35 I. Slivac, E. Zdraveva, F. Ivančić, B. Žunar, T. H. Grgurić, V. G. Srček, I. K. Svetec, T. Dolenec, E. G. Bajsić and M. T. Trcin, et al., Bioactivity comparison of electrospun pcl mats and liver extracellular matrix as scaffolds for hepg2 cells, Polymers, 2021, 13(2), 1-11, DOI: 10.3390/polym13020279.

36 S. Liu, G. Zhou, D. Liu, Z. Xie, Y. Huang, X. Wang, W. Wu and $\mathrm{X}$. Jing, Inhibition of orthotopic secondary hepatic carcinoma in mice by doxorubicin-loaded electrospun polylactide nanofibers, J. Mater. Chem. B, 2013, (1), 101-109, DOI: $10.1039 / \mathrm{c} 2$ tb00121g.

37 Y. Liu, L. Zhang, J. Wei, S. Yan, J. Yu and X. Li, Promoting hepatocyte spheroid formation and functions by coculture with fibroblasts on micropatterned electrospun fibrous scaffolds, 2014. www.rsc.org/MaterialsB, DOI: 10.1039/c3tb21779e.

38 M. Domingos, F. Intranuovo, A. Gloria, R. Gristina, L. Ambrosio, P. J. Bártolo and P. Favia, Improved osteoblast cell affinity on plasma-modified 3-D extruded PCL scaffolds, Acta Biomater., 2013, 9(4), 5997-6005, DOI: 10.1016/ j.actbio.2012.12.031.

39 T. P. Burton and A. Callanan, A Non-woven Path: Electrospun Poly(lactic acid) Scaffolds for Kidney Tissue Engineering, Tissue Eng. Regener. Med., 2018, 15(3), 301-310, DOI: 10.1007/s13770-017-0107-5.

40 M. Rampichová, E. Košt’áková Kuželová, E. Filová, J. Chvojka, J. Šafka, M. Pelcl, J. Daňková, E. Prosecká, M. Buzgo, M. Plencner, D. Lukáš and E. Amlera, Composite 3D printed scaffold with structured electrospun nanofibers promotes chondrocyte adhesion and infiltration, Cell Adhes. Migr., 2018, 12(3), 271-285, DOI: 10.1080/19336918.2017.1385713.
41 M. B. Taskin, D. Xia, F. Besenbacher, M. Dong and M. Chen, Nanotopography featured polycaprolactone/polyethyleneoxide microfibers modulate endothelial cell response, Nanoscale, 2017, 9(26), 9218-9229, DOI: 10.1039/c7nr03326e.

42 E. Lamers, R. van Horssen, J. te Riet, F. C. M. J. M. van Delft, R. Luttge, X. F. Walboomers and J. A. Jansen, The influence of nanoscale topographical cues on initial osteoblast morphology and migration, Eur. Cells Mater., 2010, 20, 329-343, DOI: 10.22203/eCM.v020a27.

43 V. A. Schulte, M. Díez, M. Möller and M. C. Lensen, Surface topography induces fibroblast adhesion on intrinsically nonadhesive poly(ethylene glycol) substrates, Biomacromolecules, 2009, 10(10), 2795-2801, DOI: 10.1021/bm900631s.

44 L. Moroni, R. Licht, J. de Boer, J. R. de Wijn and C. A. van Blitterswijk, Fiber diameter and texture of electrospun PEOT/PBT scaffolds influence human mesenchymal stem cell proliferation and morphology, and the release of incorporated compounds, Biomaterials, 2006, 27(28), 4911-4922, DOI: 10.1016/j.biomaterials.2006.05.027.

45 A. F. Von Recum and T. G. Van Kooten, The influence of micro-topography on cellular response and the implications for silicone implants, J. Biomater. Sci., Polym. Ed., 1995, 7(2), 181-198, DOI: 10.1163/156856295X00698.

46 M. Ventre, C. F. Natale, C. Rianna and P. A. Netti, Topographic cell instructive patterns to control cell adhesion, polarization and migration, J. R. Soc. Interface, 2014, 11(100), 20140687, DOI: 10.1098/rsif.2014.0687.

47 S. A. Abdellatef, A. Ohi, T. Nabatame and A. Taniguchi, Induction of hepatocyte functional protein expression by submicron/nano-patterning substrates to mimic in vivo structures, Biomater. Sci., 2014, 2(3), 330-338, DOI: 10.1039/c3bm60191a.

48 X. Shi, Y. Wang, D. Li, L. Yuan, F. Zhou, Y. Wang, B. Song, Z. Wu, H. Chen and J. L. Brash, Cell adhesion on a POEGMA-modified topographical surface, Langmuir, 2012, 28(49), 17011-17018, DOI: 10.1021/la303042d.

49 J. You, V. K. Raghunathan, K. J. Son, D. Patel, A. Haque, C. J. Murphy and A. Revzin, Impact of Nanotopography, Heparin Hydrogel Microstructures, and Encapsulated Fibroblasts on Phenotype of Primary Hepatocytes, ACS Appl. Mater. Interfaces, 2015, 7(23), 12299-12308, DOI: 10.1021/ am504614e.

50 D. Lubasová, L. Martinová, D. Mareková and P. Kostecká, Cell growth on porous and non-porous polycaprolactone nanofibers, Nanocon, 2010, 10-15.

51 P. Sengupta and B. L. V. Prasad, Surface Modification of Polymers for Tissue Engineering Applications: Arginine Acts as a Sticky Protein Equivalent for Viable Cell Accommodation, ACS Omega, 2018, 3(4), 4242-4251, DOI: 10.1021/ acsomega.8b00215.

52 N. Munir, A. Mcdonald and A. Callanan, Bioprinting A combinatorial approach: Cryo-printing and electrospinning hybrid scaffolds for cartilage tissue engineering, Bioprinting, 2019, 16, e00056, DOI: 10.1016/j.bprint.2019.e00056.

53 T. P. Burton, A. Corcoran and A. Callanan, The effect of electrospun polycaprolactone scaffold morphology on 
human kidney epithelial cells, Biomed. Mater., 2017, 13(1), 15006, DOI: 10.1088/1748-605X/aa8dde.

54 J. Wesierska-Ga̧dek, M. Gueorguieva, C. Ranftler and G. Zerza-Schnitzhofer, A new multiplex assay allowing simultaneous detection of the inhibition of cell proliferation and induction of cell death, J. Cell. Biochem., 2005, 96(1), 1-7, DOI: 10.1002/jcb.20531.

55 K. J. Livak and T. D. Schmittgen, Analysis of relative gene expression data using real-time quantitative PCR and the 2- $\Delta \Delta \mathrm{CT}$ method, Methods, 2001, 25(4), 402-408, DOI: 10.1006/meth.2001.1262.

56 T. S. R. Bate, V. L. Gadd, S. J. Forbes and A. Callanan, Response differences of HepG2 and Primary Mouse Hepatocytes to morphological changes in electrospun PCL scaffolds, Sci. Rep., 2021, 11(1), 1-13, DOI: 10.1038/s41598021-81761-z.

57 D. Semnani, E. Naghashzargar, M. Hadjianfar, F. Dehghan Manshadi, S. Mohammadi, S. Karbasi and F. Effaty, Evaluation of PCL/chitosan electrospun nanofibers for liver tissue engineering, Int. J. Polym. Mater. Polym. Biomater., 2017, 66(3), 149-157, DOI: 10.1080/00914037.2016.1190931.

58 E. Malikmammadov, T. E. Tanir, A. Kiziltay, V. Hasirci and N. Hasirci, PCL and PCL-based materials in biomedical applications, J. Biomater. Sci., Polym. Ed., 2018, 29(7-9), 863-893, DOI: 10.1080/09205063.2017.1394711.

59 F. Khademi, J. Ai, M. Soleimani, J. Verdi, S. Mohammad Tavangar, E. Sadroddiny, M. Massumi and S. Mahmoud Hashemi, Improved human endometrial stem cells differentiation into functional hepatocyte-like cells on a glycosaminoglycan/collagen-grafted polyethersulfone nanofibrous scaffold, J. Biomed. Mater. Res., Part B, 2017, 105(8), 2516-2529, DOI: 10.1002/jbm.b.33758.

60 N. J. Schaub, T. Britton, R. Rajachar and R. J. Gilbert, Engineered nanotopography on electrospun PLLA microfibers modifies RAW 264.7 cell response, ACS Appl. Mater. Interfaces, 2013, 5(20), 10173-10184, DOI: 10.1021/ am402827g.

61 A. Haider, S. Haider and I. K. Kang, A comprehensive review summarizing the effect of electrospinning parameters and potential applications of nanofibers in biomedical and biotechnology, Arabian J. Chem., 2018, 11(8), 1165-1188, DOI: 10.1016/j.arabjc.2015.11.015.

62 X. Li, K. Teng, J. Shi, W. Wang, Z. Xu, H. Deng, H. Lv and F. Li, Electrospun preparation of polylactic acid nanoporous fiber membranes via thermal-nonsolvent induced phase separation, J. Taiwan Inst. Chem. Eng., 2016, 60, 636-642, DOI: $10.1016 /$ j.jtice.2015.11.012.

63 C. Huang and N. L. Thomas, Fabricating porous poly(lactic acid) fibres via electrospinning, Eur. Polym. J., 2018, 99, 464-476, DOI: 10.1016/j.eurpolymj.2017.12.025.

64 G. R. Guillen, Y. Pan, M. Li and E. M. V. Hoek, Preparation and characterization of membranes formed by nonsolvent induced phase separation: A review, Ind. Eng. Chem. Res., 2011, 50(7), 3798-3817, DOI: 10.1021/ie101928r.

65 K. Nayani, H. Katepalli, C. S. Sharma, A. Sharma, S. Patil and R. Venkataraghavan, Electrospinning combined with nonsolvent-induced phase separation to fabricate highly porous and hollow submicrometer polymer fibers, Ind. Eng. Chem. Res., 2012, 51(4), 1761-1766, DOI: 10.1021/ ie2009229.

66 L. Natarajan, J. New, A. Dasari, S. Yu and M. A. Manan, Surface morphology of electrospun PLA fibers: Mechanisms of pore formation, $R S C A d v$. , 2014, 4(83), 44082-44088, DOI: 10.1039/c4ra06215a.

67 Z. Qi, H. Yu, Y. Chen and M. Zhu, Highly porous fibers prepared by electrospinning a ternary system of nonsolvent/ solvent/poly(l-lactic acid), Mater. Lett., 2009, 63(3-4), 415-418, DOI: 10.1016/j.matlet.2008.10.059.

68 P. Y. Chen and S. H. Tung, One-Step Electrospinning to Produce Nonsolvent-Induced Macroporous Fibers with Ultrahigh Oil Adsorption Capability, Macromolecules, 2017, 50(6), 2528-2534, DOI: 10.1021/acs.macromol.6b02696.

69 C. J. Luo, E. Stride and M. Edirisinghe, Mapping the influence of solubility and dielectric constant on electrospinning polycaprolactone solutions, Macromolecules, 2012, 45(11), 4669-4680, DOI: 10.1021/ma300656u.

70 C. Huang and N. L. Thomas, Fabricating porous poly(lactic acid) fi bres via electrospinning, Eur. Polym. J., 2018, 99, 464-476, DOI: 10.1016/j.eurpolymj.2017.12.025.

71 A. Rianjanu, A. Kusumaatmaja, E. A. Suyono and K. Triyana, Solvent vapor treatment improves mechanical strength of electrospun polyvinyl alcohol nanofibers, Heliyon, 2018, 4(4), e00592, DOI: 10.1016/j.heliyon.2018.e00592.

72 C. T. Lim, E. P. S. Tan and S. Y. Ng, Effects of crystalline morphology on the tensile properties of electrospun polymer nanofibers, Appl. Phys. Lett., 2008, 92(14), 141908, DOI: 10.1063/1.2857478.

73 D. J. Subach, Biodegradable polymers, Elsevier, 4th edn, 1997, DOI: 10.1016/B978-0-12-398358-9.00023-9.

74 H. Lee, K. Yamaguchi, T. Nagaishi, M. Murai, M. Kim, K. Wei, K. Q. Zhang and I. S. Kim, Enhancement of mechanical properties of polymeric nanofibers by controlling crystallization behavior using a simple freezing/thawing process, RSC Adv., 2017, 7(69), 43994-44000, DOI: 10.1039/c7ra06545k.

75 S. C. Wong, A. Baji and S. Leng, Effect of fiber diameter on tensile properties of electrospun poly(e-caprolactone), Polymer, 2008, 49(21), 4713-4722, DOI: 10.1016/j.polymer.2008.08.022.

76 M. F. Leong, K. S. Chian, P. S. Mhaisalkar, W. F. Ong and B. D. Ratner, Effect of electrospun poly(D,L-lactide) fibrous scaffold with nanoporous surface on attachment of porcine esophageal epithelial cells and protein adsorption, J. Biomed. Mater. Res., Part A, 2009, 89(4), 1040-1048, DOI: 10.1002/jbm.a.32061.

77 O. Braissant, M. Astasov-Frauenhoffer, T. Waltimo and G. Bonkat, A Review of Methods to Determine Viability, Vitality, and Metabolic Rates in Microbiology, Front. Microbiol., 2020, 11(2), 1-25, DOI: 10.3389/fmicb.2020.547458.

78 L. Peternel, M. Kotnik, A. Preželj and U. Urleb, Comparison of 3 cytotoxicity screening assays and their application to the selection of novel antibacterial hits, J. Biomol. Screening, 2009, 14(2), 142-150, DOI: 10.1177/1087057108329452. 
79 V. M. C. Quent, D. Loessner, T. Friis, J. C. Reichert and D. W. Hutmacher, Discrepancies between metabolic activity and DNA content as tool to assess cell proliferation in cancer research, J. Cell. Mol. Med., 2010, 14(4), 1003-1013, DOI: $10.1111 / \mathrm{j} .1582-4934.2010 .01013 . x$.

80 D. E. Heath, J. J. Lannutti and S. L. Cooper, Electrospun scaffold topography affects endothelial cell proliferation, metabolic activity, and morphology, J. Biomed. Mater. Res., Part A, 2010, 94(4), 1195-1204, DOI: 10.1002/jbm.a.32802.

81 S. N. Rampersad, Multiple applications of alamar blue as an indicator of metabolic function and cellular health in cell viability bioassays, Sensors, 2012, 12(9), 12347-12360, DOI: 10.3390/S120912347.

82 M. R. Buchakjian and S. Kornbluth, The engine driving the ship: Metabolic steering of cell proliferation and death, Nat. Rev. Mol. Cell Biol., 2010, 11(10), 715-727, DOI: 10.1038/nrm2972.

83 I. Ozaki, M. Motomura, Y. Setoguchi, N. Fujio, K. Yamamoto, T. Kariya and T. Sakai, Albumin mRNA expression in human liver diseases and its correlation to serum albumin concentration, Gastroenterol. Jpn., 1991, 26(4), 472-476, DOI: 10.1007/BF02782816.

84 M. Hayashi, S. Nomoto, M. Hishida, Y. Inokawa, M. Kanda, Y. Okamura, Y. Nishikawa, C. Tanaka, D. Kobayashi and S. Yamada, et al., Identification of the collagen type 1 alpha 1 gene (COL1A1) as a candidate survival-related factor associated with hepatocellular carcinoma, BMC Cancer, 2014, 14(1), 1-10, DOI: 10.1186/1471-2407-14-108.

85 N. J. Schaub, A. R. D’Amato, A. Mason, D. T. Corr, E. Y. Harmon, M. R. Lennartz and R. J. Gilbert, The effect of engineered nanotopography of electrospun microfibers on fiber rigidity and macrophage cytokine production, J. Biomater. Sci., Polym. Ed., 2017, 28(13), 1303-1323, DOI: 10.1080/09205063.2017.1321345.

86 J. A. Reid, A. Mcdonald and A. Callanan, Modulating electrospun polycaprolactone scaffold morphology and composition to alter endothelial cell proliferation and angiogenic gene response, PLoS One, 2020, 15(10), e0240332, DOI: 10.1371/journal.pone.0240332.

87 D. Rajendran, A. Hussain, D. Yip, A. Parekh, A. Shrirao and C. H. Cho, Long-term liver-specific functions of hepatocytes in electrospun chitosan nanofiber scaffolds coated with fibronectin, Avicenna J. Med. Biotechnol., 2017, 105(8), 2119-2128, DOI: 10.1002/jbm.a.36072.
88 S. Gnavi, B. E. Fornasari, C. Tonda-Turo, G. Ciardelli, M. Zanetti, S. Geuna and I. Perroteau, The influence of electrospun fibre size on Schwann cell behaviour and axonal outgrowth, 2014, [accessed 2021 Jun 25], DOI: 10.1016/ j.msec.2014.12.055.

89 M. Chen, P. K. Patra, S. B. Warner and S. Bhowmick, Role of fiber diameter in adhesion and proliferation of NIH 3T3 fibroblast on electrospun polycaprolactone scaffolds, Tissue Eng., 2007, 13(3), 579-587, DOI: 10.1089/ten.2006.0205.

90 I. Fasolino, V. Guarino, M. Marrese, V. Cirillo, M. Vallifuoco, M. L. Tamma, V. Vassallo, A. Bracco, F. Calise and L. Ambrosio, HepG2 and human healthy hepatocyte in vitro culture and co-culture in PCL electrospun platforms, Biomed. Mater., 2018, 13(1), 015017, DOI: 10.1088/ 1748-605X/aa8c51.

91 Y. Kim, Y. W. Kim, S. B. Lee, K. Kang, S. Yoon, D. Choi, S.-H. Park and J. Jeong, Hepatic patch by stacking patientspecific liver progenitor cell sheets formed on multiscale electrospun fibers promotes regenerative therapy for liver injury, Biomaterials, 2021, 274, 120899, DOI: 10.1016/ j.biomaterials.2021.120899.

92 Vinken M, Editors VR. Protocols in In Vitro Hepatocyte Research Methods in Molecular Biology 1250, 2015, https://link.springer. com/content/pdf/10.1007\%2F978-1-4939-2074-7.pdf.

93 N. Lu, C. Lu, S. Yang and J. Rogers, Highly sensitive skinmountable strain gauges based entirely on elastomers, $A d v$. Funct. Mater., 2012, 22(19), 4044-4050, DOI: 10.1002/ adfm.201200498.

94 R. Harjumäki, R. Wahyu, N. Nugroho, X. Zhang, Y.-R. Lou, M. Yliperttula, J. J. Valle-Delgado and M. Österberg, Quantified forces between HepG2 hepatocarcinoma and WA07 pluripotent stem cells with natural biomaterials correlate with in vitro cell behavior, Sci. Rep., 2019, 9, 7354, DOI: 10.1038/s41598-019-43669-7.

95 R. Grant, D. Hay and A. Callanan, From scaffold to structure: The synthetic production of cell derived extracellular matrix for liver tissue engineering, Biomed. Phys. Eng. Express, 2018, 4(6), 065015, DOI: 10.1088/2057-1976/aacbe1.

96 C. Weigert, S. Sefried, H.-U. Häring and S. S. Eckstein, Suitability of hepatocyte cell lines HepG2, AML12 and THLE-2 for investigation of insulin signalling and hepatokine gene expression, Open Biol., 2018, 8(10), DOI: 10.1098/ rsob.180147. 